EPiC Series in Built Environment
Volume 1, 2020, Pages 437-446
Associated Schools of Construction Proceed-
ings of the 56th Annual International Conference

\title{
Evaluating the Feasibility of using Corn Ash and Wood Ash in Concrete in Florida
}

\author{
Ishan Sathe \\ NY Developers and Management LLC \\ Brooklyn, NY
}

\author{
Abdol Chini, Ph.D. \\ University of Florida \\ Gainesville, FL
}

\begin{abstract}
The use of fly ash in concrete has seen a steady rise in the last few decades. Several government agencies in the US have specified a minimum quantity of fly ash as a substitute for Portland cement in concrete. In recent years, the generation of fly ash has reduced due to the decreasing reliance on using coal power plants and it is necessary to start looking at alternative options. Wood ash and corn ash have been considered as potential replacements to fly ash in concrete in countries like Nigeria and India. US is the largest producer of corn with majority of the production in the Midwest. Similarly, plenty of wood waste is available in Florida with almost 2.7 million metric tons being landfilled annually. This study used the literature data on properties of corn ash and wood ash and the test results on their use in concrete to demonstrate the feasibility of using them as a substitute for fly ash in production of low strength concrete in Florida. The environmental impacts of using fly ash along with corn ash and wood ash were also calculated and compared.
\end{abstract}

Keywords: Corn Ash, Wood Ash, Low Strength Concrete, Environmental Impacts, Waste Products

\section{Introduction}

Concrete is one of the widely used construction materials in the world today. It is estimated that concrete production would be around 18 billion tons by 2050 (Aprianti et al., 2015). This has put a large strain on raw materials and non-renewable natural resources. Construction is said to be a significant source of Greenhouse Gas (GHG) emissions (Junnila and Horvath, 2003). Therefore, increase in concrete production will lead to increase in GHG emissions. Portland cement is an important ingredient in concrete. The increase in concrete demand has meant that the cement production has increased causing an increase in carbon emissions. The cement production worldwide in 2012 was approximately 3,800 million metric tons (MMT) while in 2018 it increased to 4,100 MMT (US Geological Survey, 2019). The increase in cement consumption has been due to population increase, better infrastructure facilities, and improved standard of living. It is estimated that for every ton of cement produced, around 0.73-0.99 tons of $\mathrm{CO}_{2}$ is emitted (Hasanbeigi et al., 2012). Approximately half of these emissions are due to the combustion of fossil fuels as production of cement requires about 4-5GJ/ton of energy (Celik et al., 2015). This increase in carbon emissions has led to expanded efforts on studying alternative materials as a replacement to cement in concrete. 
Use of industrial waste like fly ash, blast furnace slag and silica fume in concrete has been going on for a long time now. Use of these waste products in concrete has prevented million metric tons from entering landfills. Fly ash and blast furnace slag are byproducts of coal combustion and iron and steel manufacturing process, respectively. As these waste products have efficient pozzolanic properties, their use in concrete has produced positive results. Many government agencies in US have promoted the use of fly ash in concrete. For example, the Florida Department of Transportation requires a minimum $18 \%$ of fly ash as a replacement of Portland cement in concrete.

In recent years, the generation of fly ash has reduced because of the ill effects of coal combustion. But the demand for fly ash has remained constant. With the increasing reliance on fly ash in the production of concrete, the reduction in the availability of fly ash is a source of concern. Therefore, it has become necessary to look for alternative materials as a potential replacement of fly ash. Corn ash and wood ash are the relatively new products that have been proposed for use as partial replacements to cement. These products are found to have good pozzolanic properties and can be a good replacement to fly ash in concrete. Wood waste is used in biomass plants as a raw material for generating renewable energy. These biomass plants emit wood ash as a byproduct like fly ash in coal combustion process. Thus, the potential of wood ash generation is significant. About $20 \%$ of the solid waste generated in Florida consists of wood and yard trimmings (US EPA 1, 2012). Similarly, corn waste generation is significant as the US is the largest producer of corn. Therefore, corn waste can also be considered for using as a raw material in biomass plants. The ash generated, can be used as a partial replacement to fly ash in concrete. This study used the literature data on properties of corn ash and wood ash and the test results on their use in concrete to demonstrate the feasibility of using them as a substitute for fly ash in production of low strength concrete in Florida. It also examined the environmental impact and cost implications of using corn ash and wood ash to replace Portland cement in production of low strength concrete in Florida (Sathe, 2017).

\section{Supplementary Cementitious Materials}

Supplementary Cementitious Materials (SCM's) can be divided in two categories based on the type of reaction they undergo: hydraulic and pozzolan. Hydraulic materials react directly with water to form cementitious compounds while pozzolanic materials react to form C-S-H gel in the presence of water that has concrete like properties. The purpose of using SCM's like fly ash and slag cement is to reduce the cement content in concrete. Industrial wastes such as fly ash and blast furnace slag along with agricultural wastes like corn cob ash and wood ash are being used as supplementary materials for partial replacement of cement. These materials contain aluminum oxide and silica oxide, which react with calcium hydroxide to form compounds having cementitious properties. Reusing these wastes can reduce cement consumption resulting in reduction of cost of concrete production. Use of these SCM's can reduce the waste sent to landfills, reduce consumption of raw materials, and reduce energy consumption and $\mathrm{CO}_{2}$ emissions.

Figure 1 shows the fly ash production has been declining since 2010, but its use has remained constant over the years. Hence, the fly ash used as a percent of produced has significantly risen to more than $50 \%$. By this rate, the fly ash production and consumption will end up being equal and eventually will lead to a shortage of supply. A survey conducted by the American Coal Ash Association in 2012 highlighted different parameters to find out the use of these materials in construction. It observed that there can be a potential increase in the use of SCM from the existing 60 $\mathrm{Kg} / \mathrm{m}^{3}$ to $85 \mathrm{Kg} / \mathrm{m}^{3}$. Assuming all the increase is attributed to fly ash and slag cement, and the production levels of concrete continue to rise, the percentage use of fly ash and slag cement will rise from $41 \%$ to an all-time high of $61 \%$. This means a strain on the availability of fly ash and slag cement in the future assuming the current reduction in the supply of these two materials continues. 


\section{Corn Ash}

United States is the largest producer of corn having 52\% of the world production. According to the US Department of Agriculture, more than 36.5 million hectares of corn are grown in the US with the majority of the crop grown in the Heartland region. Corn is used mainly for livestock feed; in food products like starch, syrups, corn oil, beverage; and fuel ethanol. Corn cob is a waste product that is ultimately crushed and landfilled. Corn cob ash has pozzolanic properties which is therefore a suitable replacement for cement in concrete production. Use of corn cob and corn stover in biomass plants for electricity generation can reduce their disposal in landfill that end up polluting land, air and water.

Fly Ash Production and Use with Percent

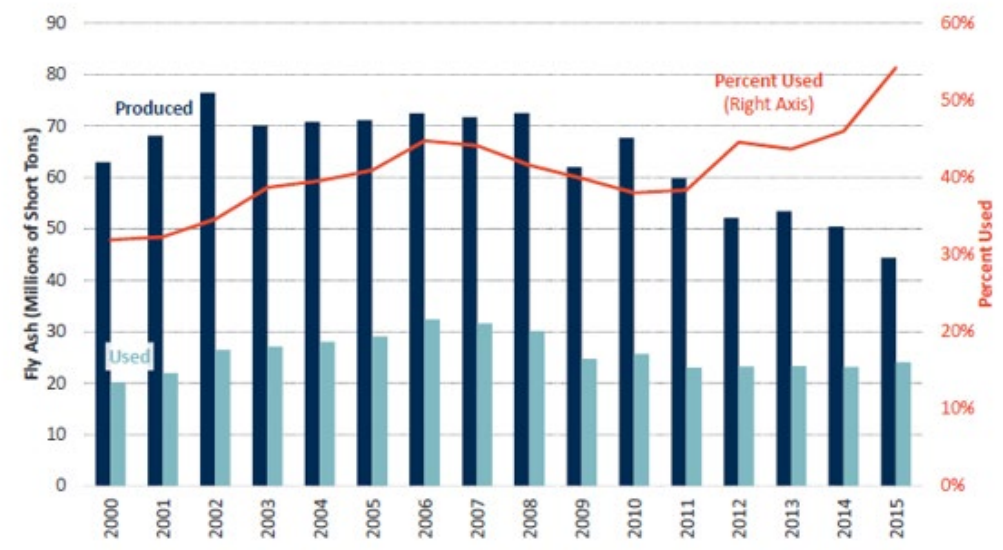

Figure 1. The fly ash production and use statistics (adopted from American Coal Ash Association)

Several researchers studied properties of concrete made with different percentages of corn cob ash (CCA) as a replacement of Portland cement. These properties included compressive strength, flexural strength, thermal conductivity, and insulation value. The results showed that CCA can be used as partial replacement for cement in production of low-strength concrete but replacement should not exceed $10 \%$ as strength produced above this replacement level may not be adequate to meet the strength requirements (Ahangba and Tiza, 2016). Olafusi and Olutoge (2016) also concluded that the use of CCA as a partial replacement for cement in concrete, particularly in plain concrete works and non-load bearing structures, will enhance waste to wealth initiative. They also observed that water requirement increase with increase in percentage of CCA replacement and the CCA concrete would take longer time to achieve its designed strength. Another study showed that thermal conductivity of CCA concreate decreased and its insulation value increased with a $25 \%$ corn cob ash replacement (Adesanya and Raheem 2009).

\section{Wood Ash}

Wood ash is the residue generated due to the combustion of wood and its products like chips, saw dust bark etc. Wood ash is a byproduct generated from the combustion in boilers at pulp mills, steam power plants and other thermal power generating facilities. The major problem of using timber waste product as a fuel is the generation of ash. There is a large amount of wood waste ash generated and available to be used for different purposes. Almost $70 \%$ of the wood waste is deposited in the environment in different forms (Aprianti et al. 2015). Biomass, which consists of forestry and 
agricultural wastes, is a considerable source of renewable energy. Landfilling is the most prevalent method accounting for $70 \%$ of the ash generated from wood combustion, $20 \%$ wood ash is used as soil supplement while the rest is used on miscellaneous jobs (Chowdhury et al. 2015). The physical and chemical properties of wood ash depend on the species of wood, the combustion temperature, efficiency of the boiler and supplementary fuels used. The use of wood ash in concrete can reduce the disposal problems and reduce the cost of concrete. Etiegni (1990) studied the effect of combustion temperature on yield and chemical properties of wood ash. Naik et al. (2003) studied the chemical composition of different types of wood ash and found that some of them did not meet American Society of Testing Materials (ASTM) C 618 criteria.

Chowdhury et al. (2015) studied the compressive, flexural and tensile strengths of concrete with different percentages $(5 \%, 10 \%, 15 \%, 18 \%$ and $20 \%)$ of blended wood ash cement. They observed that these strengths decreased marginally with increase in wood ash contents but recovered at later ages. Subramaniam et al. (2015) studied the use of wood ash as a partial replacement to cement for manufacturing concrete blocks. They observed that the compressive strength of blocks with $20 \%$ wood ash replacement was comparable with the control specimen. The optimum wood ash replacement percent that gave the best results was found to be 15\%. Sashidhar and Rao (2010) also studied the effects of replacement of cement with wood ash. They observed that $\mathrm{H}_{2} \mathrm{SO}_{4}$ attack on wood ash is severe as it resulted in a decrease in strength of concrete. Ten percent wood ash replacement had the minimum acid attack. The water absorption capacity was found to decrease with increase in wood ash content from zero to $30 \%$.

\section{Properties of Corn Ash and Wood Ash}

Physical properties including specific gravity, $\mathrm{pH}$, moisture content and bulk density of corn ash and wood ash found in literature (Aprianti et al, 2015; Subramaniam et al, 2015; Naik et al, 2003) were compared with those of fly ash (Table 1). The moisture content of corn ash was found to vary depending on the type of combustion process as well as the percentage of corn cob, leaves and stalks burnt in the biomass plants. The specific gravity and bulk density of corn ash was in the same range as that of fly ash, which suggested that the mass to volume ratio of corn ash and fly ash were the same.

The $\mathrm{pH}$ for wood ash varies between 9 and 13.5 indicating varying levels of alkalinity. The range of specific gravity values $(0.16-1.4)$ are due to the varying percentages of chips, sawdust and bark in the wood waste. The moisture content of wood ash is very low compared to fly ash. To produce high quality cement based products incorporating wood ash, not only must the moisture content be kept low but the variability in moisture content must be minimized. Low moisture content in wood ash would also reduce the transportation cost to the concrete gate.

Table 1. Comparison of physical properties of corn ash, wood ash and fly ash.

\begin{tabular}{lccc}
\hline Properties & Corn Ash & Wood Ash & Fly Ash \\
\hline Specific Gravity & 1.15 & $0.16-1.4$ & $0.9-1.3$ \\
pH & 6 & $9-13$ & $8-10$ \\
Moisture Content & $20 \%$ & $2.60 \%$ & $18-38 \%$ \\
Bulk Density & $1153 \mathrm{~kg} / \mathrm{m}^{3}$ & $162-1371 \mathrm{~kg} / \mathrm{m}^{3}$ & $897-1297 \mathrm{~kg} / \mathrm{m}^{3}$ \\
\hline
\end{tabular}

Chemical property comparison consisted of the individual properties of corn ash, wood ash, and fly ash found in literature (Aprianti et al, 2015; Subramaniam et al, 2015; Naik et al, 2002). ASTM C 618 specifies the use of fly ash in concrete and requires fly ash to have more than $70 \%$ silica, alumina and 
calcium content to be a good pozzolan. As there was no separate specification for corn ash or wood ash they were compared with ASTM C 618 requirements. Table 2 shows that the combined percentage of silica $\left(\mathrm{SiO}_{2}\right)$, alumina $\left(\mathrm{Al}_{2} \mathrm{O}_{3}\right)$ and calcium oxide $(\mathrm{CaO})$ for corn ash is more than $70 \%$, which is an indication of good pozzolanic properties. These compounds are responsible for the formation of calcium aluminum hydrates when reacting in the presence of calcium hydroxide and water. The loss of ignition (LOI) value requirement for Portland cement is a maximum of 6 under ASTM C 618. The LOI value for corn ash is high (21.4\%), indicating a higher mass-change.

For wood ash the minimum 70\% requirement of silicon dioxide, aluminum oxide and iron oxide falls short, the combined percentage is equal to $63 \%$. Wood ash swells because of hydration of silicates and the lime present in the ash. The loss of ignition is $31.6 \%$, which is significantly higher than the maximum of $6 \%$ required for pozzolanic materials per ASTM C618 specification. This is because of the substantial amount of unburnt carbon present in wood ash. The alkali content $\left(\mathrm{Na}_{2} \mathrm{O}\right)$ is higher $(6.5 \%)$ than the maximum required $(1.5 \%)$.

Table 2. Comparison of chemical properties of wood ash, corn ash and fly ash.

\begin{tabular}{lccc}
\hline $\begin{array}{l}\text { Chemical } \\
\text { Properties }\end{array}$ & Corn Ash & Wood Ash & Fly Ash \\
\hline Silicon Dioxide & $22.10 \%$ & $50.70 \%$ & $38.0-63.0 \%$ \\
Aluminum Dioxide & $4.50 \%$ & $8.20 \%$ & $27.0-44.0 \%$ \\
Iron Dioxide & $3.90 \%$ & $9.80 \%$ & $3.3-6.4 \%$ \\
Calcium Oxide & $62.20 \%$ & $3.50 \%$ & $0.2-8.0 \%$ \\
Magnesium Oxide & $2.50 \%$ & $0.70 \%$ & $0.01-0.5 \%$ \\
Potassium Oxide & $0.80 \%$ & $1.10 \%$ & $0.04-0.9 \%$ \\
Sodium Oxide & $0.40 \%$ & $0.90 \%$ & $0.07-0.43 \%$ \\
Loss Of Ignition & $21.40 \%$ & $31.60 \%$ & $0.2-5.0 \%$ \\
\hline
\end{tabular}

\section{Properties of Concrete Made with Corn Ash and Fly Ash}

Physical properties of concrete made with corn ash and wood ash found in the literature were compared with those made with fly ash (Olafusi and Olutoge, 2012; Raheem et al, 2010; Sashidhar and Sudarsana, 2010). These properties included soundness, initial setting time, final setting time, slump and compressive strength. Table 3 shows that the initial and final setting time of corn and wood ash concrete are higher than fly ash concrete due to the reduction in surface area of cementitious materials that delay the hydration process. The 28 -day compressive strength of concrete with corn ash decreases with increasing corn ash percentages. The 28 -day strength of concrete with $10 \%$ corn ash replacement (20 MPa) meets the minimum requirement of $21 \mathrm{MPa}$. The strength increase is slow because of the lower percentage of highly reactive silica reducing the rate of hydration. The slump of corn ash concrete is like that of normal concrete suggesting that the corn ash does not affect the workability of concrete. The 28 -day compressive strength for $15 \%$ wood ash replacement is $21.7 \mathrm{MPa}$ indicating that for $21 \mathrm{MPa}$ compressive strength concrete, a maximum of $15 \%$ cement can be replaced with wood ash. There is a significant gain in strength at a later age due to the slow pozzolanic activity of wood ash. The slump value of concrete containing wood ash is very low indicating less workable concrete. This indicates that more water would be required to increase the workability. 
Table 3. Comparison of physical properties of concrete made with wood ash, corn ash and fly ash.

\begin{tabular}{lccc}
\hline Properties & $\begin{array}{c}\text { Corn Ash, 10\% } \\
\text { Replacement }\end{array}$ & $\begin{array}{c}\text { Wood Ash. 15\% } \\
\text { Replacement }\end{array}$ & $\begin{array}{c}\text { Fly Ash, 20\% } \\
\text { Replacement }\end{array}$ \\
\hline Initial Setting Time & $208 \mathrm{~min}$ & $135 \mathrm{~min}$ & $30 \mathrm{~min}$ \\
Final Setting Time & $328 \mathrm{~min}$ & $283 \mathrm{~min}$ & $200 \mathrm{~min}$ \\
Slump & $28.5 \mathrm{~mm}$ & $2.5 \mathrm{~mm}$ & $10-30 \mathrm{~mm}$ \\
Compressive & $20.0 \mathrm{MPa}$ & $21.7 \mathrm{MPa}$ & $33.0 \mathrm{MPa}$ \\
Strength (28 Days) & $3.0 \mathrm{~mm}$ & $1.1 \mathrm{~mm}$ & $10 \mathrm{~mm}$ \\
Soundness & & & \\
\hline
\end{tabular}

\section{Feasibility Study}

The review of literature in previous sections showed that corn ash and wood ash can be used as replacement for fly ash in low-strength concrete. The studies that tested the compressive strength of concrete samples with incremental percentages of corn ash or wood ash concluded that the optimum replacement percentages of corn ash and wood ash to achieve $21 \mathrm{MPa}$ concrete is $10 \%$ and $15 \%$, respectively. In this section the availability, environmental impact, and cost of these ashes are calculated to evaluate their feasibility to replace fly ash when there is a need.

\section{Cement Consumption for Low Strength Concrete}

Based on the Portland Cement Association data (PCA, 2016) the average annual cement consumption in Florida from 2003-2016 was 4.4 million metric ton (MMT). The cement consumption for readymix concrete production was 70\% of the total consumption, 3.0 MMT (Statista 1). Per National Ready-Mix Concrete Association (NRMCA) data, about $64 \%$ of the total concrete consumption in the south-east region of the US had less than $24 \mathrm{MPa}$ strength. Therefore, the annual cement consumption for low-strength concrete was calculated to be 2.0 MMT.

\section{Corn Ash and Wood Ash Demand and Supply Analysis}

The annual corn ash demand in Florida was determined as $10 \%$ of the 2.0 MMT annual cement consumption or 200,000 MT. Per US Department of Agriculture, Florida has 16,000 hectare of corn production. With 360 bushel/hectare, there is a total 5,760,000 bushels of corn production in Florida annually (USDA). The amount of ash generation depends on the quantity of corn stover remaining after harvest. This corn stover consists of bales, stalks, leaves and cob. One hundred forty-five bushels of corn produce 7.4 dry MT of corn stover per hectare (Khanna and Paulson, 2016). Therefore, the total quantity of corn stover generated annually in Florida is 118,400 MT. The ash generation for corn cob, husk, leaves and stalk is about 5\% (Lizotte et al. 2015). Thus, the potential corn ash generation in Florida is approximately 6,000 MT which is only $3 \%$ of the 200,000 MT demand calculated above.

The annual wood ash demand in Florida was determined as 15\% of the 2.0 MMT annual cement consumption or 300,000 MT. Per Florida Department of Environmental Protection, nearly 13.5 MMT of solid waste is landfilled annually. About $20 \%$ of the total solid waste is composed of wood and yard trimmings (US EPA 1). Therefore, Florida has approximately 2.7 MMT of wood waste that is landfilled annually. Alternatively, wood waste materials can be used in biomass power plants to generate electricity. Florida has currently 18 biomass plants, among the most in the US (Biomass, 
2019 ) and the scope of generating wood ash is increasing every year. Assuming a conservative $4 \%$ ash generation from the biomass plant, the potential quantity of wood ash available in Florida is $108,000 \mathrm{MT}$, which is $37 \%$ of the $300,000 \mathrm{MT}$ demand calculated above.

\section{Environmental Impacts}

The environmental impacts of all materials were calculated by comparing the difference in greenhouse gas emissions associated with transporting one MT of corn ash, wood ash and fly ash to the concrete plant gate. As all materials under consideration are byproducts, the processing energy associated with acquiring the materials was taken as zero. Therefore, the greenhouse gas emissions consist of only the transportation energy emissions. These emissions were from the combustion of fossil fuels required to transport the material to the concrete gate. Transportation energy was measured in metric tons of carbon equivalent per metric ton of material transported. Therefore, the sources of corn ash, wood ash and fly ash nearest to Orlando and Miami were selected. Orlando was chosen because of its central location in Florida and Miami because of the increasing construction activities under way in south Florida. The source of wood ash was the biomass plant in Gainesville, FL. The source of fly ash was the coal combustion plant in Lakeland, FL. Currently, corn ash is not produced in the US. It was assumed that the corn waste was used in biomass plants to generate corn ash as a byproduct. Therefore, the source of corn ash was taken as the IHI Power Services Corporation biomass plant in Brooksville, FL.

Google Map was used for calculating the distance. The fuel used for transportation was taken as diesel. The transportation combustion energy factor for each material is the product of the combustion energy factor for diesel (0.001 MBTU/MT-km) (US EPA 2) and the distance travelled. The fuel specific carbon coefficient of (0.02 MTCE/MBTU) was used (US EPA 2). The transport energy emissions of $\mathrm{CO}_{2}$ were calculated to obtain the transportation greenhouse gas emissions (Table 4). The transportation energy emissions due to $\mathrm{CH}_{4}$ were negligible as compared to $\mathrm{CO}_{2}$.

Table 4. Transportation Energy Emissions in MTCE/MT.

\begin{tabular}{lcccccc}
\hline Material & $\begin{array}{c}\text { Distance to } \\
\text { Orlando } \\
(\mathbf{k m})\end{array}$ & $\begin{array}{c}\text { Combustion } \\
\text { Energy } \\
\text { MBTU/MT }\end{array}$ & $\begin{array}{c}\text { Energy Co2 } \\
\text { Emissions } \\
\text { MTCE/MT }\end{array}$ & $\begin{array}{c}\text { Distance to } \\
\text { Miami } \\
(\mathbf{k m})\end{array}$ & $\begin{array}{c}\text { Combustion } \\
\text { Energy } \\
\text { MBTU/MT }\end{array}$ & $\begin{array}{c}\text { Energy Co2 } \\
\text { Emissions } \\
\text { MTCE/MT }\end{array}$ \\
\hline Corn Ash & 129 & 0.129 & 0.0026 & 129 & 0.129 & 0.0026 \\
Wood Ash & 182 & 0.182 & 0.0036 & 69 & 0.069 & 0.0014 \\
Fly Ash & 89 & 0.089 & 0.0018 & 167 & 0.167 & 0.0033 \\
\hline
\end{tabular}

Table 4 shows that transportation emissions for corn ash were lower than wood ash in Orlando but higher in Miami. Fly ash had the lowest greenhouse gas emissions in Orlando but the highest emissions in Miami. This was because of the proximity of the fly ash source to Orlando. With the current location of biomass plant, the transportation energy values for corn ash and wood ash were higher than fly ash in Orlando. In contrast, due to the proximity of biomass plants near Miami, the transportation energy values of wood ash and corn ash were lower than those of fly ash. With upcoming addition of biomass plants in Florida, it would be possible to reduce the transportation distances and the energy emissions associated with use of corn and wood ash. 


\section{Cost}

The availability and cost play an important role when evaluating the feasibility of using any materials. The cement industry is affected by regulatory norms because of strict environmental issues. The average price of cement in the United States is \$143/MT (Statista, 2). The reason for the high cement price is the processing energy and raw materials spent in manufacturing cement. Cement prices also depend on the current economic situation. Fly ash prices have been steady over the years. However, recent closure of coal plants, has resulted in a decrease in fly ash production. The cost of fly ash was \$39/MT. The American Road \& Transportation Builders Association report predicted the utilization of fly ash to grow by $2.2 \%$ per year. However, the production of fly ash, is projected to grow at only $0.1 \%$ per year. The fly ash utilization rate was $45 \%$ in the United States in 2013 , which is predicted to increase to $63 \%$ by 2033 (ARTBA). This difference in production and demand may create availability problems in the future. A reduction in availability may lead to increased fly ash prices. The cost of wood ash was taken as \$26-42/MT. Currently corn ash is not used as a raw material in biomass plants. Therefore, the cost of corn ash was not available. The cost of corn stover in Florida was not available because of limited availability. Therefore, the cost of corn stover from the Midwest was taken for reference. To get a better estimate of price in Florida, a 10\% increase was considered to offset the increase in price due to reduction in availability. Therefore, the cost of corn stover was estimated as \$50-83/MT.

The current market cost of wood ash is comparable to fly ash. Therefore, it can be used without affecting the current cost of concrete. The cost of corn stover is found to vary depending on location and market condition. Due to limited availability, this cost is bound to be on the higher side. Using corn stover to replace fly ash will increase the cost per ton of concrete. In addition, burning wood waste materials in biomass power plants will reduce the cost of dumping them in landfills. The average cost of waste disposal charged by landfill sites for yard trash is \$33/MT. This will help save $\$ 89.1$ million because of the 2.7 MMT of wood waste generated annually in Florida.

\section{Conclusions}

Based on the properties of corn ash and wood ash found in literature, they can be suitable replacement to fly ash in low-strength concrete applications. The potential availability of wood ash in Florida is $108,000 \mathrm{MT}$. This is $37 \%$ of the $300,000 \mathrm{MT}$ annual wood ash demand in Florida to replace $15 \%$ of the annual cement consumption. However, the potential availability of corn ash is very low and satisfy only $3 \%$ of corn ash needed. Therefore, it will be necessary to look at additional sources of corn ash, possibly from the Midwest region. Although, the cost of transporting this corn ash to Florida would be high and is not feasible. The difference in cost per metric ton of wood ash and fly ash is small (\$5/MT). Therefore, wood ash can be considered as a partial replacement to fly ash. The difference in cost per metric ton of corn ash and fly ash is high (\$25/MT) which would result in a considerable increase in cost of concrete. Overall, wood ash meets the feasibility criteria (physical/chemical properties, availability, environmental impact, and cost) identified in this paper to replace fly ash in production of low-strength concrete in Florida. Whereas, corn ash availability is limited, it costs more than fly ash, and therefore, not a feasible substitute for fly ash.

The data used for comparing the physical and chemical properties of concrete containing wood ash and corn ash were not based in Florida. Many papers studied were from outside the US. The properties of wood ash and corn ash are dependent on the type of wood waste and corn waste. More experimental work such as studying the compressive and tensile strengths of concrete made with wood ash and corn ash will help to explain properties of wood ash and corn ash obtained from sources 
in Florida. The transportation energy emissions are based on the transportation distances of wood and corn ash from biomass plants. Therefore, using the GIS to identify the best locations for installing biomass plants not only for the generation of electricity but also for using the byproducts for cement replacement in concrete would help reduce energy emissions.

\section{References}

Adesanya, D., \& Raheem, A. (2009). A study of the workability and compressive strength characteristics of corn cob ash blended cement concrete. Construction and Building Materials, 23(1), 311-317.

Ahangba A. S. Tiza M. (2016), Partial replacement of cement with corn cob ash, International Journal for Innovative Research in Multidisciplinary Field volume 2, issue 7, July 2016US

American Coal Ash Association, Fly Ash Production and Use, Retrieved December 11, 2019, from https://www.acaa-usa.org/Portals/9/Files/PDFs/2015-Survey_Results_Charts.pdf

American Road and Transportation Builders Association (ARTBA), Production and use of Coal Combustion Product in US, Retrieved December 11, 2019, https://www.acaausa.org/Portals/9/Files/PDFs/ReferenceLibrary/ARTBA-final-forecast.compressed.pdf

Aprianti, E., Shafigh, P., Bahri, S., \& Farahani, J. N. (2015). Supplementary cementitious materials origin from agricultural wastes - A review. Construction and Building Materials, 74, 176187.doi:http://dx.doi.org/10.1016/j.conbuildmat.2014.10.010

Biomass Magazine, US Biomass Power Plants, Retrieved December 11, 2019, http://biomassmagazine.com/plants/listplants/biomass/US/

Celik, K., Meral, C., Petek Gursel, A., Mehta, P. K., Horvath, A., \& Monteiro, P. J. M. (2015). Mechanical properties, durability, and life-cycle assessment of self-consolidating concrete mixtures made with blended Portland cements containing fly ash and limestone powder. Cement and Concrete Composites, 56, 59-72. doi:http://dx.doi.org/10.1016/j.cemconcomp.2014.11.003

Chowdhury, S., Maniar, A., \& Suganya, O. (2015). Strength development in concrete with wood ash blended cement and use of soft computing models to predict strength parameters. Journal of Advanced Research, 6(6), 907-913.

Etiegni, L. (1990). Wood Ash Recycling and Land Disposal, FHWA research and technology. Retrieved 03/18, 2017, from https://www.fhwa.dot.gov/publications/research/infrastructure/structures/97148/bfs3.cfm

Hasanbeigi, A., Price, L., \& Lin, E. (2012). Emerging energy-efficiency and CO 2 emission-reduction technologies for cement and concrete production: A technical review. Renewable and Sustainable Energy Reviews, 16(8), 6220-6238.

Junnila, S., \& Horvath, A. (2003). Life-cycle environmental effects of an office building. Journal of Infrastructure Systems, 9(4), 157-166.

Lizotte, P., \& Savoie, P. (2011). Spring harvest of corn stover. Applied Engineering in Agriculture, 27(5), 697.

Khanna, M. and Paulson, K. (2016), To Harvest Stover or Not: Is it Worth it? University of Illinois, Retrieved December 11, 2019, https://farmdocdaily.illinois.edu/2016/02/to-harvest-stover-or-not-is-it-worthit.html

Malhotra, V. M., \& Ramezanianpour, A. (1994). Fly ash in concrete, CANMET

Naik, T. R., Kraus, R. N., \& Siddique, R. (2003). Use of wood ash in cement-based materials. Center for by-Products Utilization (CBU-2003-19)

Olafusi O. s. and Olutoge S. A. (2012), Strength Properties of Corn Cob Ash Concrete, Journal of Emerging Trends in Engineering and Applied Sciences (JETEAS) 3 (2): 297-301

Portland Cement Association, Florida Cement Industry, Retrieved December 11, 2019, https://www.cement.org/docs/default- source/ga-pdfs/cement-industry-by-state2015/florida.pdf?sfvrsn $=2 \&$ sfvrsn $=2$

Raheem, A. A., Oyebisi, S. O., Akintayo, S. O., \& Oyeniran, M. I. (2010). Effects of admixtures on the properties of corn-cob ash cement concrete. Leonardo Electronic Journal of Practices and Technologies, 16, 13-20.

Sashidhar, C., \& Sudarsana Rao, H. (2010). Durability studies on concrete with wood ash additive. Paper presented at the 35th Conference on our World in Concrete and Structures. Http://cipremier. com/100035048,

Sathe, I. (2017), Evaluating the Feasibility of using Corn Ash and Wood Ash in Concrete in Florida, Master Thesis, University of Florida, https://ufdc.ufl.edu/UFE0051561/00001 
Statista 1, US cement use in 2018, by user group, Retrieved December 11, 2019, https://www.statista.com/statistics/248714/us- cement-use-by-user-group/

Statista 2, Cement prices in the United States from 2007 to 2018, Retrieved December 11, 2019, https://www.statista.com/statistics/219339/us-prices-of-cement/

Subramaniam, P., Subasinghe, K., \& Fonseka, W. K. (2015). Wood ash as an effective raw material for concrete blocks. International Journal of Research in Engineering and Technology, 4(2), 2319-1163.

US Department of Agriculture, 2018 State Agriculture Overview, Retrieved December 11, 2019, https://www.nass.usda.gov/Quick Stats/Ag_Overview/stateOverview.php?state=FLORIDA

US Environmental Protection Agency 1, Municipal Solid Waste Generation, Recycling, and Disposal in the United States: Facts and Figures for 2012, Retrieved December 11, 2019, https://www.epa.gov/sites/production/files/2015-09/documents/2012 msw fs.pdf

US Environmental Protection Agency 2, Fuels Registration, Reporting, and Compliance Help, Retrieved December 11, 2019, https://www.epa.gov/fuels-registration-reporting-and-compliance-help/summarytable-lifecycle-greenhouse-gasemissions

US Geological Survey. Cement production globally and in the US from 2010 to 2018. In Statista. Retrieved December 11, 2019, from https:/www.statista.com/statistics/219343/cement-production-worldwide/ 